\title{
KEMAMPUAN PEMECAHAN MASALAH MAHASISWA CALON PENDIDIK MATEMATIKA
}

\author{
Nola Nari \\ Program Studi Tadris Matematika, Jurusan Tarbiyah, STAIN Batusangkar \\ Korespondensi: Jl.Sudirman No. 137 Kuburajo, Lima Kaum, Batusangkar, Sumatera Barat \\ E-mail: nolanari84@gmail.com
}

\begin{abstract}
This research was inspired from the result of a research under the title: "Analisis kemampuan pemecahan masalah matematis mahassiswa program studi tadris matematika." This research was done to know and describe how was the students' ability to solve mathematic probelm as math teacher candidate in Geometri Transformasi subject registered in 2012/2013 academic year of Mathematic department of Tarbiyah Faculty of STAIN Batusangkar. The design of this research was the combination of quantitative and qualitative by using descriptive approach. The instrument of this research was test and interview. The data was analyzed through data triangulation, data reduction, data presentation, and making conclusion. The result of the research showed that the students' ability from high group was very satisfactory. The students' ability from avarage group was satisfactory. And, the students' ability from low group was almost satisfactory.
\end{abstract}

Kata kunci: Kemampuan pemecahan masalah, matematis

\section{PENDAHULUAN}

$\mathrm{P}$ ada pasal 10 Undang-undang Guru dan Dosen yang disyahkan oleh DPR pada bulan Desember 2005 disebutkan bahwa guru dan dosen yang profesional harus mempunyai empat kompentensi atau kemampuan utama yaitu: kemampuan pedagogik, profesional, kepribadian dan sosial. Untuk kompentensi pedagogik, guru dan dosen dituntut untuk mampu menyiapkan materi pembelajaran, mengajarkannya di kelas dan mengevaluasinya. Untuk itu seorang Dosen dan guru (pendidik) matematika harus mampu melakukan evaluasi dan menganalisis berbagai kemampuan siswa yang salah satunya adalah kemampuan pemecahan masalah.
Kemampuan pemecahan masalah seyogyanya merupakan hasil utama dari suatu proses pembelajaran matematika. Menurut Utari (2014: 197) pemecahan masalah matematik mempunyai dua makna yaitu sebagai suatu pendekatan dan sebagai tujuan pembelajaran. Dalam kondisi ini pemecahan masalah dikatakan sebagai target belajar (Ahmad Fauzan: 2013: 2), meskipun tercantum dalam tujuan yang ingin dicapai dalam kurikulum matematika, namun kemampuan pemecahan masalah matematis ini belum menjadi perhatian khusus sehingga tidak dianalisis. Tanpa menganalisis kemampuan pemecahan masalah matematis mahasiswa, pendidik akan memiliki sedikit keterangan, data, dan fakta tentang pemahaman mahasiswa dalam melakukan proses dan 
aplikasi matematika terutama dalam pemecahan masalah matematis. Hal ini senada dengan pendapat Suke dalam Ali Hamzah (2014: 71) tujuan utama melakukan evaluasi dalam suatu proses pembelajaran adalah untuk mendapatkan informasi yang akurat mengenai tingkat pencapaian tujuan pembelajaran oleh siswa sehingga dapat diupayakan tindak lanjutnya. Dengan menganalisis kemampuan mahasiswa, maka pendidik dapat mengetahui cara berpikir mahasiswa dalam memecahkan masalah dan mengetahui tingkat penguasaan materi mahasiswa. Pengetahuan pendidik tentang pemikiran mahasiswa adalah pedoman yang penting dalam merencanakan perkuliahan yang aktif dalam upaya tindak lanjut untuk menghasilkan calon pendidik yang kompeten di bidang pendidikan matematika.

Sekolah Tinggi Agama Islam Negeri (STAIN) Batusangkar sebagai salah satu institusi pendidikan yang memiliki Program Studi Tadris Matematika, juga memiliki persoalan dan tantangan yang sama dalam menghasilkan calon pendidik matematika. Berdasarkan hasil pengamatan selama mengampu perkuliahan khususnya mata kuliah Geometri pada program studi Tadris Matematika ditemukan bahwa sebagian besar mahasiswa Tadris Matematika belum memiliki kecakapan dalam memecahkan masalah yang terkait dengan matematika tersebut sehingga mereka belum mampu menerapkan pengetahuan matematika yang sudah dipelajari dalam kehidupan. Setiap mahasiswa memiliki kemampuan dan cara yang beragan dalam hal pemecahan masalah. Padahal mereka seharusnya dituntut untuk mampu mengintegrasikan ilmu tersebut dengan latar belakang keislaman yang menjadi visi dan misi Program Studi Tadris Matematika dan ciri utama Sekolah Tinggi Agama Islam Negeri yang menghasilkan lulusan Sarjana Pendidikan Islam.
Untuk menghasilkan lulusan yang berkompeten dalam bidang pendidikan matematika sebagai pendidik matematika maka setiap mahasiswa dibekali dengan suatu mata kuliah yaitu Geometri. Mata kuliah Geometri merupakan mata kuliah wajib yang harus diikuti oleh setiap Mahasiswa STAIN Batusangkar secara berkelanjutan mulai dari Geometri Bidang dan Ruang dilanjutkan dengan Geometri Analitik Bidang Dan Ruang kemudian Geometri Transformasi. Pembelajaran geometri yang dapat memberikan bekal kompetensi hendaklah pembelajaran yang lebih bermakna bagi mahasiswa sehingga mereka mampu mengaplikasikan ilmu yang mereka peroleh di lapangan.

Geometri sangat berkaitan erat dengan fenomena kehidupan, mulai dari fenomena yang sederhana sampai fenomena yang kompleks. Penguasaan geometri sangat diperlukan dalam kehidupan. Penguasaan geometri ini meliputi kemampuan memahami isi (content) geometri itu sendiri, memahami kaitan antar konsep geometri, mengemukakan ide geometri ke dalam bahasanya, serta menyusun model matematika dalam menyelesaikan permasalahan (mathematical problem solving).

Pemecahan masalah telah lama dikembangkan di berbagai negara. Berbagai ahli telah melakukan penelitian berkaitan dengan pemecahan masalah. Akan tetapi, salah satu ahli yang paling memfokuskan penelitiannya pada pemecahan masalah adalah George Polya (1956), seorang ahli matematika dari Stanford University. Polya dalam bukunya How to Solve It menjelaskan bahwa terdapat empat tahap yang harus dilakukan oleh seseorang dalam memecahkan masalah. Keempat tahapan ini dinamakan model Polya.

Pembelajaran pemecahan masalah dengan model Polya dalam Suherman (2003) sangat efektif digunakan dalam pembelajaran, terutama pembelajaran 
matematika. Pembelajaran matematika yang dimaksud disini adalah geometri. Pembelajaran dengan model ini mengarahkan mahasiswa untuk dapat menyederhanakan masalah geometri yang mereka hadapi, sehingga masalah tersebut akan lebih mudah diselesaikan. Hal yang menjadi perhatian utama adalah proses pemecahan masalah yang dirangkum dalam empat tahapan Polya dalam memecahkan masalah, mahasiswa dituntut untuk mampu memanfaatkan pengetahuan mereka dalam mengumpulkan informasi yang ada pada masalah yang dihadapi. Penyederhanaan masalah dilakukan dengan cara membuat analogi, peragaan, sketsa, ilustrasi, metafora, atau keputusan induktif dalam geometri ini dapat dimunculkan dengan memberikan penafsiran gambaran geometris mengenai suatu fenomena. Strategi ini memilih cara penyederhanaan yang paling mungkin dapat dilakukan, atau yang paling masuk akal, dan yang paling sesuai dengan keadaan. Berdasarkan tahap pembelajaran tersebut maka hasil akhirnya dapat evaluasi dengan melakukan analisis terhadap kemampuan pemecahan masalah matematis mahasiswa.

$$
\text { Dalam dokumen National }
$$

Research Council tahun 1989 dinyatakan bahwa pengalaman-pengalaman yang diperoleh melalui proses pemecahan masalah matematis memungkinkan berkembangnya kekuatan matematis yang antara lain meliputi kemampuan membaca dan menganalisis situasi secara kritis, mengidentifikasi kekurangan yang ada, mendeteksi kemungkinan terjadinya bias, menguji dampak dari langkah yang akan dipilih, serta mengajukan alternatif solusi kreatif atas permasalahan yang dihadapi. Dengan demikian, pemecahan masalah matematis dapat membantu seorang calon pendidik memahami informasi yang tersebar disekitarnya secara lebih baik sehingga mampu memecahkan masalah matematika.

\section{METODE PENELITIAN}

Penelitian ini menggunakan gabungan metode kuantitatif dan kualitatif dengan pendekatan deskriptif untuk mengetahui kemampuan pemecahan masalah matematis calon pendidik matematika. Subjek penelitian ini adalah mahasiswa semester VI pada mata kuliah Geometri Transformasi. Ada tiga tahap dalam prosedur penelitian ini yaitu bagian awal, inti, dan akhir, bagian awal dengan langkah : (1) pengembangan tes mulai dari menentukan tujuan, menentukan batasan yaitu pada materi transformasi, membuat kisi-kisi soal tes dengan indikator pemecahan masalah yaitu : (1) Pemahaman apa yang diketahui tentang konsep isometric (S,M,R,H,G), (2) Pemahaman tentang apa yang ditanyakan tentang konsep isometric ( $\mathrm{S}, \mathrm{M}, \mathrm{R}, \mathrm{H}, \mathrm{G})$, (3) Ketepatan urutan langkah yang digunakan (4) Kebenaran tulisan dalam menjelaskan langkah-langkah, (5) Ketepatan/keterampilan dalam menggunakan jangkar, busur dan penggaris, (6) Ketepatan ukuran (dalam melukis bangun, garis sejajar, garis tegak lurus, dan garis yang membentuk sudut tertentu).

Kebenaran langkah.

Selanjutnya membuat soal indikator, validasi soal, setelah soal divalidasi dilakukan uji coba pada mahasiswa yang telah pernah mengambil mata kuliah Geometri Transformasi di Prodi tadris matematika STAIN Batusangkar, kemudian menentukan daya pembeda soal, taraf kesukaran, klasifikasi, dan reliabilitas soal tes, (2) melaksanakan tes pada mahasiswa semester VI yang mengambil mata kuliah Geometri transformasi pada tahun ajaran 2012/2013 kemudian skor tes kemampuan pemecahan masalah tersebut digunakan untuk pengelompokkan mahasiswa menjadi tiga kelompok, kelompok tinggi, sedang, dan rendah dengan "aturan 27\%" (Purwanta: 2009 : 107), (3) membuat pedoman wawancara, (4) pemilihan subjek 
wawancara. Bagian inti yaitu melaksanakan tes, dan bagian akhir menarik kesimpulan dari hasil tes, hasil studi mahasiswa, dan wawancara.

Peneliti adalah instrument kunci dari penelitian ini dan instrument pendukung berupa tes kemampuan pemecahan masalah, hasil studi mahasiswa, dan pedoman wawancara. Teknik pen- jamin keabsahan data yang digunakan adalah triangulasi, sedangkan teknik analisis data ada tiga tahap : (1) reduksi data yaitu analisis data yang berupa hasil tes kemampuan pemecahan masalah dan analisis hasil wawancara, analisis data yang berupa hasil tes dengan langkah (a) menentukan skor setiap item berdasarkan rubrik penilaian seperti tabel berikut:

Tabel 1: Rubrik Skala Penilaian Tingkat Kemampuan Pemecahan Masalah Matematis

\begin{tabular}{|c|c|c|}
\hline No & Aspek yang dinilai & Rubrik \\
\hline 1. & $\begin{array}{l}\text { Pemahaman apa yang diketahui tentang } \\
\text { konsep isometric }(\mathrm{S}, \mathrm{M}, \mathrm{R}, \mathrm{H}, \mathrm{G})\end{array}$ & $\begin{array}{l}\text { 1. Jika sama sekali tidak memahami } \\
\text { 2. Jika pemahamannya sebagian } \\
\text { kecil }\end{array}$ \\
\hline 2. & $\begin{array}{l}\text { Pemahaman apa yang ditanyakan } \\
\text { tentang isometric }(\mathrm{S}, \mathrm{M}, \mathrm{R}, \mathrm{H}, \mathrm{G})\end{array}$ & $\begin{array}{l}\text {-3. Jika pemahamannya sebagian } \\
\text { besar } \\
\text { 4. Jika sangat memahami }\end{array}$ \\
\hline 3. & $\begin{array}{llll}\begin{array}{l}\text { Ketepatan urutan langkah yang } \\
\text { digunakan }\end{array} & \\
\end{array}$ & \\
\hline 4. & $\begin{array}{l}\text { Kebenaran tulisan dalam menjelaskan } \\
\text { langkah-langkah }\end{array}$ & \\
\hline 5. & $\begin{array}{l}\text { Ketepatan/Keterampilan dalam meng- } \\
\text { gunakan jangka, busur, dan penggaris }\end{array}$ & \\
\hline 6. & $\begin{array}{l}\text { Ketepatan ukuran (dlm melukis } \\
\text { bangun,garis sejajar,garis tegak lurus, } \\
\text { dan garis yang membentuk sudut } \\
\text { tertentu }\end{array}$ & \\
\hline 7. & Kebenaran jawaban & \\
\hline
\end{tabular}

(b) menghitung jumlah skor hasil tes,

(c) menentukan persentase (d) menentu- kan predikat skor hasil tes dengan tabel 2 sebagai berikut:

Tabel 2: Predikat Kemampuan Pemecahan Masalah Matematis Siswa

\begin{tabular}{ll}
\hline \multicolumn{1}{c}{ Kategori } & \multicolumn{1}{c}{ Kriteria } \\
\hline $\mathrm{A}=$ Sangat memuaskan & $81 \%-100 \%$ \\
\hline $\mathrm{B}=$ Memuaskan & $61 \%-80 \%$ \\
\hline $\mathrm{C}=$ Cukup memuaskan & $41 \%-60 \%$ \\
\hline $\mathrm{D}=$ Kurang memuaskan & $21 \%-40 \%$ \\
\hline $\mathrm{E}=$ Tidak memuaskan & $0 \%-20 \%$ \\
\hline
\end{tabular}

Setelah hasil tes dikategorikan berdasarkan kriteria dalam tabel 2 di atas maka dilanjutkan dengan menyajikan data, dan menarik kesimpulan dari data yang telah terkumpul. 
HASIL DAN PEMBAHASAN

Hasil dari penelitian yang diperoleh dari tes kemampuan pemecahan masalah terdapat pada tabel 3 berikut:

Tabel 3: Kemampuan Pemecahan Masalah Berdasarkan Indikator

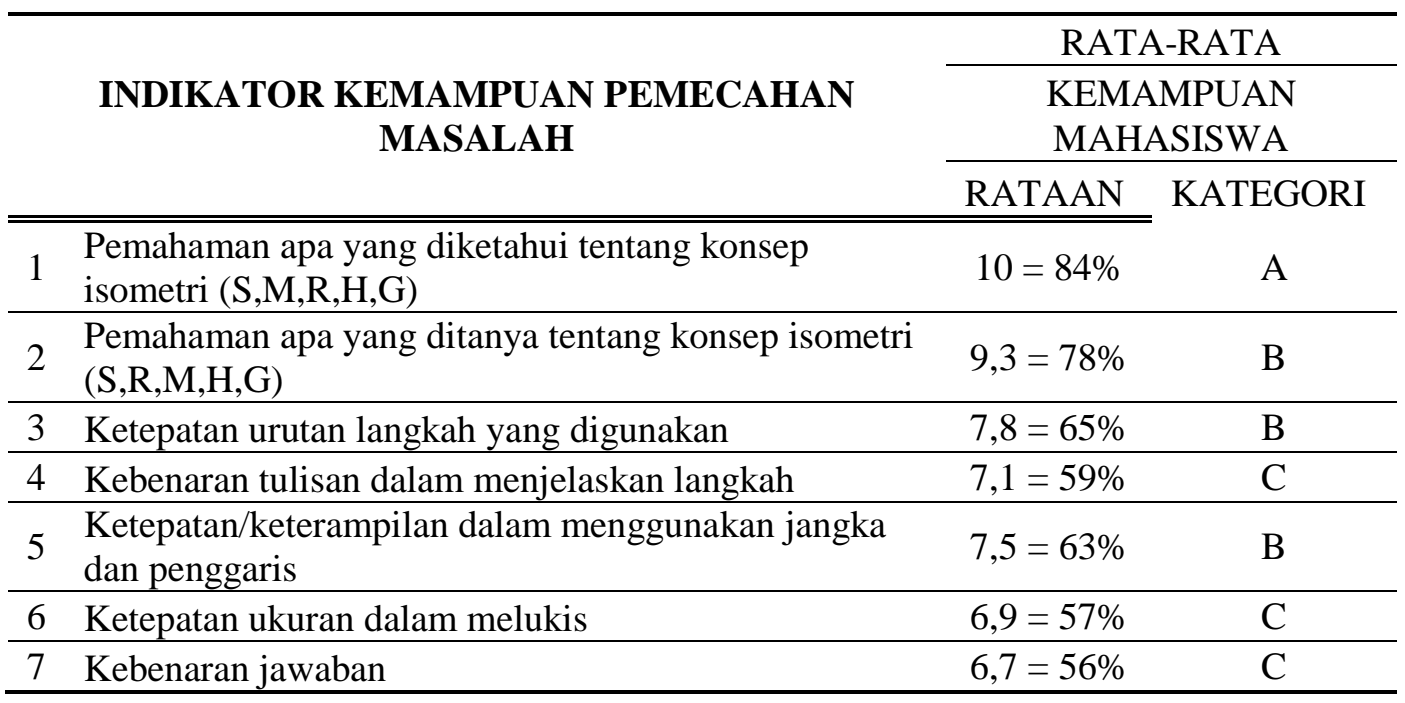

Tabel 4 : Kemampuan Pemecahan Masalah Berdasarkan Kemampuan Mahasiswa

\begin{tabular}{ccccccccc}
\hline \multirow{2}{*}{$\begin{array}{c}\text { KELOMPO } \\
\text { K }\end{array}$} & \multicolumn{9}{c}{ PERSENTASE SKOR } & \multicolumn{3}{c}{ RATAAN } \\
\cline { 2 - 9 }$y$ & 1 & 2 & 3 & 4 & 5 & 6 & 7 & KPM \\
\hline \hline TINGGI & 97.06 & 96.08 & 86.27 & 81.37 & 79.41 & 76.47 & 77.45 & 84.87 \\
\hline & $\mathrm{A}$ & $\mathrm{A}$ & $\mathrm{A}$ & $\mathrm{A}$ & $\mathrm{B}$ & $\mathrm{B}$ & $\mathrm{B}$ & $\mathrm{A}$ \\
\hline SEDANG & 85.28 & 77.78 & 63.06 & 56.94 & 62.78 & 54.44 & 53.33 & 64.80 \\
\hline & $\mathrm{A}$ & $\mathrm{B}$ & $\mathrm{B}$ & $\mathrm{C}$ & $\mathrm{B}$ & $\mathrm{C}$ & $\mathrm{C}$ & $\mathrm{B}$ \\
\hline RENDAH & $\mathrm{67.65}$ & 59.31 & 46.57 & 40.69 & 45.10 & 42.65 & 39.71 & 48.81 \\
\hline & $\mathrm{B}$ & $\mathrm{C}$ & $\mathrm{C}$ & $\mathrm{D}$ & $\mathrm{C}$ & $\mathrm{C}$ & $\mathrm{D}$ & $\mathrm{C}$ \\
\hline
\end{tabular}

Dalam penelitian yang dilakukakan ini diperoleh data tentang kemampuan pemecahan masalah matematis mahasiswa calon pendidik matematika pada mata kuliah Geometri Transformasi yang terlihat pada tabel 4 di atas yang meliputi 7 indikator kemampuan pemecahan masalah yaitu pemahaman apa yang diketahui tentang konsep isometric $(\mathrm{S}, \mathrm{M}, \mathrm{R}, \mathrm{H}, \mathrm{G})$, pemahaman apa yang ditanya tentang konsep isometric $(\mathrm{S}, \mathrm{M}, \mathrm{R}, \mathrm{H}, \mathrm{G})$, ketepatan urutan langkah yang digunakan, kebenaran tulisan dalam menjelaskan langkah, ketepatan/ keterampilan dalam menggunakan jangka dan penggaris, ketepatan ukuran dalam melukis, kebenaran jawaban.
Tes yang diberikan merupakan tes kemampuan pemecahan masalah dengan soal pemecahan masalah kontekstual yang memenuhi semua karakteristik soal pemecahan masalah agar tersedianya kemungkinan banyak jawaban serta tersedia keleluasaan bagi mahasiswa untuk memakai sejumlah metode yang dianggapnya paling sesuai dalam menyelesaikan masalah sehingga dapat merangsang kemampuan intelektual dan pengalaman mahasiswa dalam proses menemukan penyelesaian masalah dan penarikan kesimpulan dengan tepat.

Penggunaan soal pemecahan masalah lebih memberikan kesempatan kepada mahasiswa calon pendidik matematika untuk mengembangkan kom- 
petensi mereka dalam menggunakan ekspresi matematika/memparaprase masalah. Tidak saja kemampuan kognitif dari segi penggunaan sejumlah dalil dan dan teorema dalam pemecahan masalah tetapi mahasiswa dituntut untuk memiliki kemampuan dalam ranah afektif dan psikomotorik. Kemampuan ini ditunjukkan dengan kemampuan mereka dengan ketepatan/keterampilan dalam menggunakan jangka dan penggaris serta ketepatan mereka dalam melukis geometri. Ketiga kemampuan ini terintegrasi dengan baik sehingga mahasiswa dapat menemukan berbagai alternatif cara penyelesaian masalah. Dalam upaya menemukan berbagai alternatif strategi atau solusi suatu masalah, mahasiswa calon pendidik matematika akan menggunakan segenap kemampuannya dalam menggali berbagai informasi atau konsep-konsep yang relevan yang ada pada dirinya. Hal demikian akan mendorong mahasiswa calon pendidik matematika menjadi lebih kompeten dalam memahami ideide matematika dengan kombinasi kemampuan kognitif, afektif dan psikomotorik,

Berdasarkan hasil tes dapat diperoleh informasi bahwa rata-rata kemampuan pemecahan masalah matematis mahasiswa baru dalam kategori memuaskan. Kemampuan pemecahan masalah untuk setiap kelompok dapat terlihat pada Gambar 1 berikut:

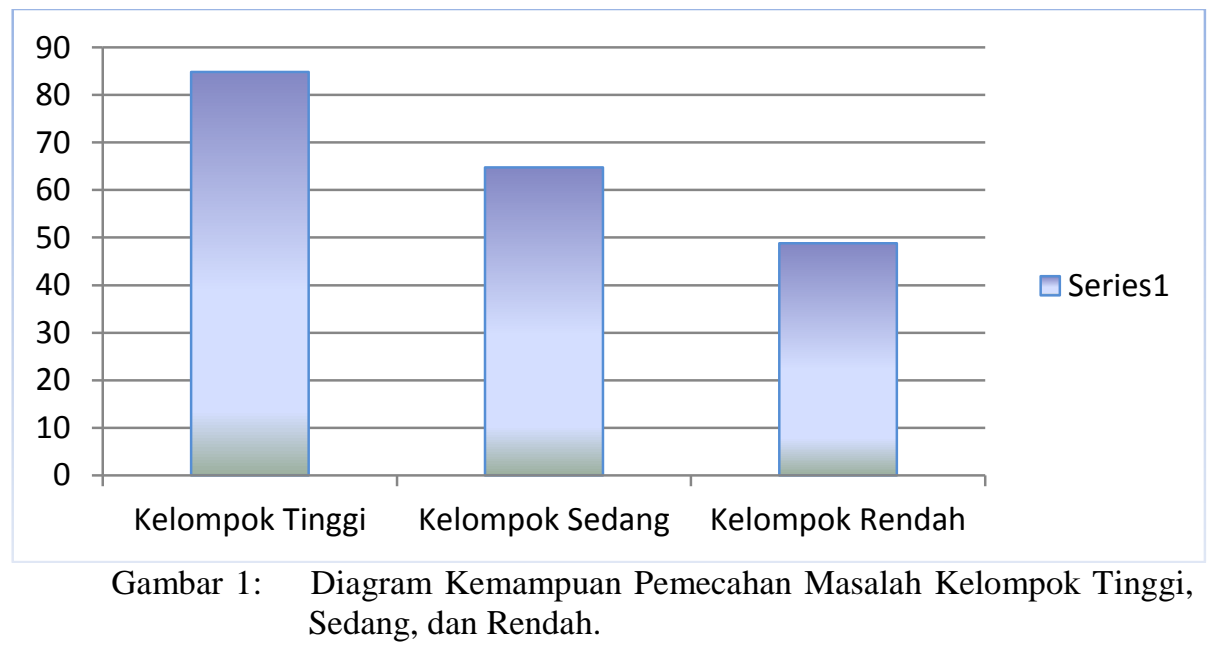

Berdasarkan Gambar 1 terlihat bahwa kemampuan pemecahan masalah matematis mahasiswa calon pendidik matematika untuk setiap kelompok berbeda. Hal ini menunjukkan keberagaman kemampuan dalam memecahkan masalah yang diberikan. Menurut Fauzan (2013) menyatakan bahwa pemecahan masalah yang kreatif tidak berarti sudah menemukan penyelesaian yang baik, tetapi juga mempertimbangkan siapa pelakunya, bagaimana pro-

sedurnya, dan bagaimana penyelesaian dilaksanakan. Untuk melihat lebih jelas kemampuan pemecahan masalah matematis calon pendidik untuk setiap indikator yang telah dijelaskan dalam tabel 9 dapat disajikan dalam bentuk diagram batang seperti gambar 11 berikut: 


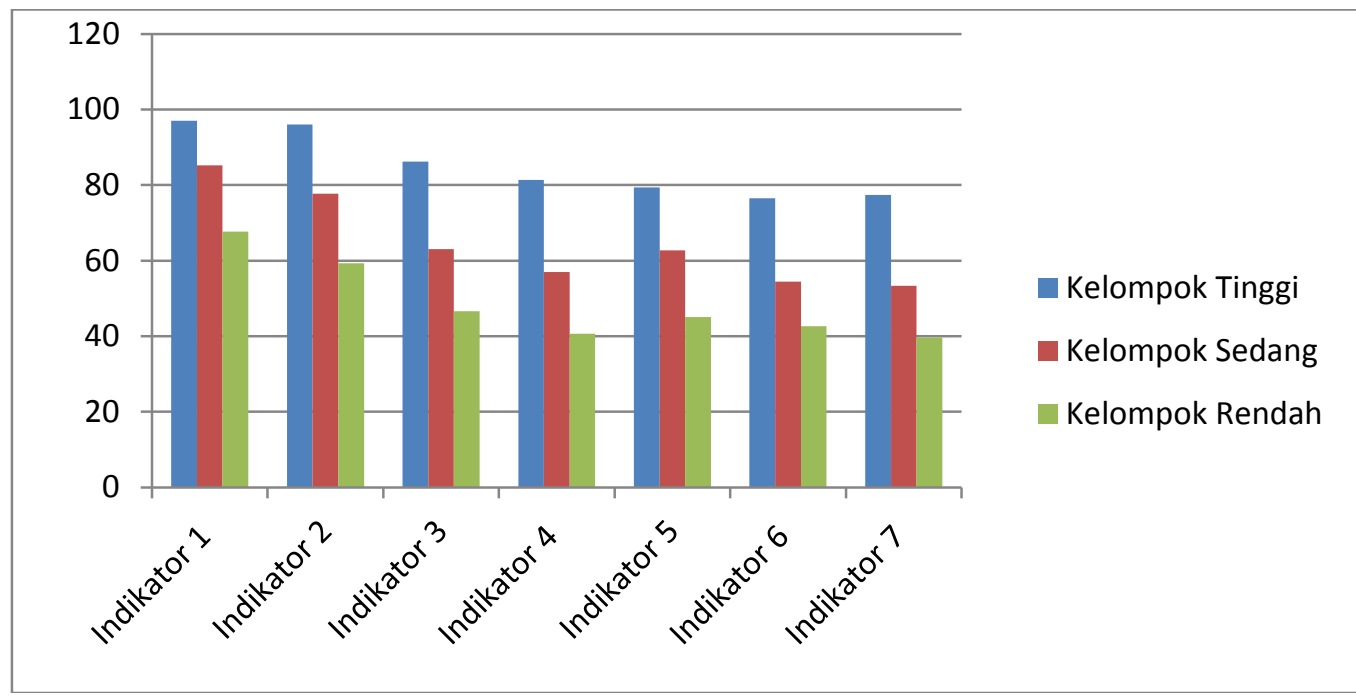

Gambar 2 : diagram Kemampuan Pemecahan Masalah Matematis untuk Setiap Indikator Mahasiswa Kelompok Tinggi, Sedang, dan Rendah.

Berdasarkan Gambar 2 terlihat rata-rata kemampuan pemecahan masalah yang berbeda untuk setiap kelompok dan setiap indikator kemampuan pemecahan masalah. Pembahasan lebih lanjut tentang kemampuan pemecahan masalah setiap kelompok akan dipaparkan sebagai berikut:

1. Kemampuan pemecahan masalah mahasiswa calon pendidik matematika pada kelompok tinggi

Kelompok tinggi sangat memuaskan dalam mengidentifikasi masalah berupa pemahaman apa yang diketahui tentang konsep isometri $(\mathrm{S}, \mathrm{M}, \mathrm{R}, \mathrm{H}, \mathrm{G})$, sangat memuaskan tentang apa yang ditanya tentang konsep isometri $(\mathrm{S}, \mathrm{M}, \mathrm{R}, \mathrm{H}, \mathrm{G})$, sangat memuaskan dalam menyelesaikan masalah berupa ketepatan urutan langkah yang digunakan, sangat memuaskan dalam kebenaran tulisan dalam menjelaskan langkah, memuaskan dalam ketepatan/keterampilan dalam menggunakan jangka dan penggaris, memuaskan dalam ketepatan ukuran dalam melukis dan memuaskan dalam menyelesaikan masalah dengan kebenaran jawaban. Hal ini menandakan mahasiswa kelompok tinggi sangat memanfaatkan makna dari pemberian permasalahan berupa soal pemecahan masalah kontekstual, padahal dengan diberikan model tes ini diharapkan dapat mengungkap strategi solusi yang berbeda dari permasalahan.

Mahasiswa telah menggunakan beberapa strategi dan sewaktu diwawancarai mahasiswa mengetahui strategi lain yang dapat digunakan untuk menyelesaikan permasalahan yang diberikan dan mahasiswa juga mengungkapnya sewaktu tes. Menurut pendapat Hamzah (2008: 134) untuk memecahkan masalah matematika melalui pengumpulan data/ fakta, menganalisis informasi, menyusun berbagai alternatif dan memilih pemecahan masalah yang paling efektif. Hal ini dapat dilakukan oleh mahasiswa calon pendidik pada kelompok tinggi sehingga hasil tes dan hasil wawancara menunjukkan hasil yang maksimal. Menurut pendapat Ahmad Fauzan (2013) tersebut diperkuat oleh Buhaeroh bahwa : Dalam memformulasikan masalah, salah satu hal yang dilakukan adalah mempresentasikan masalah secara matematik dalam berbagai bentuk apakah dalam bentuk numerik, bentuk simbolik, bentuk verbal atau bentuk grafik. 
Sama juga halnya dengan indikator pertama dan kedua mahasiswa kelompok tinggi juga mampu memberikan jawaban yang lebih baik sewaktu diwawancarai dan sewaktu tes mahasiswa telah mengungkapkan secara lengkap hal yang diketahui, unsur-unsur yang belum lengkap, kejelasan permasalahan sehingga hasil yang diperoleh sewaktu tes menyebabkan kemampuan pada indikator 1 hampir sama baiknya dengan indikator 2 dan kemampuan pada indikator 2 lebih baik dari indikator 3 .

Dengan tingginya kemampuan mahasiswa pada indikator memecahkan masalah sesuai prosedur dan ketepatan langkah yang digunakan berarti mahasiswa memahami masalah yang diberikan dimana indikator 1 dan 2 dapat dikatakan indikator yang mengukur pemahaman masalah. Sebagaimana pendapat Suherman (2003: 91) yaitu tanpa adanya pemahaman terhadap masalah yang diberikan mahasiswa tidak mungkin mampu menyelesaikan masalah dengan benar.

Berdasarkan hasil kerja mahasiswa kelompok tinggi terlihat mahasiswa kelompok tinggi dapat menentukan dengan jeli apa yang diketahui dan apa yang ditanyakan serta menguraikan kejelasan permasalahan. Mahasiswa mencatat halhal penting untuk mempermudah memahami masalah dan mempermudah mendapatkan gambaran umum penyelesaian masalah. Hal ini senada dengan pendapat Max A. Sobel (2002: 153) bahwa aktivitas visual dapat memperingan pikiran peserta didik dan membuat mereka fleksibel dan lebih kreatif sehingga pemikiran dan analisis geometri dapat memberi peserta didik alat pemecah masalah yang kuat yang sering menawarkan cara pandang yang baru terhadap situasi yang menantang.
Selain itu mahasiswa juga harus mengetahui makna dari hal yang diketahui, dan ditanyakan sehingga mahasiswa dapat menuangkan permasalahan dalam kalimat yang mudah dimengerti atau membuat model matematika dari permasalahan. Bukanlah hal yang bijak jika dalam proses memecahkan masalah arah yang akan dituju sudah teridentifikasi secara jelas. Hal ini berhubungan dengan esensialnya pemecahan masalah diberikan agar mahasiswa menjadi terampil menyeleksi informasi yang relevan, kemudian menganalisanya dan meneliti hasilnya. Sesuai dengan G. Polya dalam Hamzah Opu (2003: 35), prosedur yang ditempuh dalam memeriksa jawaban adalah memeriksa setiap langkah apakah sudah benar atau belum dan bagaimana membuktikan bahwa langkah yang dipilih sudah benar. Dengan demikian dapat disimpulkan kemampuan pemecahan masalah mahasiswa kelompok tinggi terkategori sangat memuaskan untuk setiap indikator yang telah dirumuskan.

2. Kemampuan mahasiswa kelompok sedang

Kelompok sedang terkategori sangat memuaskan dengan kategori pemahaman apa yang diketahui tentang konsep isometri ( $\mathrm{S}, \mathrm{M}, \mathrm{R}, \mathrm{H}, \mathrm{G})$ dengan lengkap, memuaskan tentang apa yang ditanya tentang konsep isometri (S,M,R,H,G), memuaskan dalam menyelesaikan masalah berupa ketepatan urutan langkah yang digunakan, cukup memuaskan dalam kebenaran tulisan dalam menjelaskan langkah, memuaskan dalam ketepatan/keterampilan dalam menggunakan jangka dan penggaris, cukup memuaskan dalam ketepatan ukuran dalam melukis dan cukup memuaskan dalam menyelesaikan masalah dengan kebenaran jawaban. Sebagaimana 
pendapat Hamzah sebelumnya berarti jika terdapat kesalahan dalam pengumpulan data atau menganalisis masalah tentunya akan mempengaruhi dalam menyusun alternatif penyelesaian.

3. Kemampuan pemecahan masalah mahasiswa kelompok rendah

Kelompok rendah terkategori memuaskan dengan kategori pemahaman apa yang diketahui tentang konsep isometri (S,M,R,H,G), cukup memuaskan tentang apa yang ditanya tentang konsep isometri ( $S, M, R, H, G)$, cukup memuaskan dalam menyelesaikan masalah berupa ketepatan urutan langkah yang digunakan, tidak memuaskan dalam kebenaran tulisan dalam menjelaskan langkah, cukup memuaskan dalam ketepatan/keterampilan dalam menggunakan jangka dan penggaris, cukup memuaskan dalam ketepatan ukuran dalam melukis dan tidak memuaskan dalam menyelesaikan masalah dengan kebenaran jawaban. Jika terdapat kesalahan dalam pengumpulan data atau menganalisis masalah tentunya akan mempengaruhi dalam menyusun alternatif penyelesaian.

Namun berdasarkan hasil tes terlihat mahasiswa telah berusaha menemukan solusi walaupun solusi yang diberikan tidak tepat sebagaimana pendapat Suherman (2003: 92) berbagai kesulitan ini muncul antara lain karena mencari jawaban dipandang sebagai satu-satunya tujuan yang ingin dicapai, karena hanya berfokus pada jawaban, mahasiswa seringkali salah dalam memilih teknik penyelesaian yang sesuai.

Berdasarkan hasil tes kemampuan pemecahan masalah terlihat mahasiswa lebih mengutamakan menyelesaikan masalah sesuai prosedur, mahasiswa kurang mengembangkan kemampuannya dalam mengidentifikasi dan memparaprase masalah. Semestinya kemampuan ini harus juga dikembangkan sebagai- mana diungkap oleh Suherman (2003: 170) kemampuan kognitif mahasiswa berkembang selaras kematangan mahasiswa. Mahasiswa itu berkembang dari mampu menyelesaikan masalah dalam satu langkah ke penyelesaian masalah dalam banyak langkah dengan disertai kemampuan memahami masalah dan menangkap lebih banyak variabel dan faktor dalam suatu masalah. Selain itu mahasiswa semestinya juga harus mengembangkan kemampuan mahasiswa dalam menyelesaikan masalah dengan strategi yang berbeda.

\section{PENUTUP}

Berdasarkan analisis data yang dikaitkan dengan pertanyaan penelitian, maka dapat disimpulkan kemampuan pemecahan masalah matematis mahasiswa tadris matematika pada mata kuliah geometri transformasi melalui tes kemampuan pemecahan masalah adalah sebagai berikut:

1. Kemampuan pemecahan masalah matematis siswa kelompok tinggi dengan setiap indikator:

a. Mengidentifikasi masalah berupa pemahaman apa yang diketahui tentang konsep isometric (S,M,R,G,H) sangat memuaskan.

b. Mengidentifikasi masalah berupa pemahaman mahasiswa tentang apa yang ditanya tentang konsep isometric $(\mathrm{S}, \mathrm{M}, \mathrm{R}, \mathrm{G}, \mathrm{H})$ sangat memuaskan.

c. Ketepatan urutan langkah yang digunakan mahasiswa sangat baik.

d. Kebenaran tulisan dalam menjelaskan langkah sangat baik.

e. Ketepatan/keterampilan dalam menggunakan jangka dan penggaris memuaskan.

f. Ketepatan ukuran dalam melukis sangat memuaskan.

g. Kebenaran jawaban terkategori sangat memuaskan. 
Jadi secara keseluruhan kemampuan pemecahan masalah matematis siswa kelompok tinggi sangat memuaskan.

2. Kemampuan pemecahan masalah matematis siswa kelompok sedang dengan setiap indikator :

a. Mengidentifikasi masalah berupa pemahaman apa yang diketahui tentang konsep isometric (S,M,R,G,H) sangat memuaskan.

b. Mengidentifikasi masalah berupa pemahaman mahasiswa tentang apa yang ditanya tentaang konsep isometric $(\mathrm{S}, \mathrm{M}, \mathrm{R}, \mathrm{G}, \mathrm{H})$ memuaskan.

c. Ketepatan urutan langkah yang digunakan mahasiswa memuaskan.

d. Kebenaran tulisan dalam menjelaskan langkah terkategori cukup memuaskan.

e. Ketepatan/keterampilan dalam menggunakan jangka dan penggaris memuaskan.

f. Ketepatan ukuran dalam melukis cukup memuaskan.

g. Kebenaran jawaban terkategori sangat cukup memuaskan.

Jadi secara keseluruhan kemampuan pemecahan masalah matematis siswa kelompok sedang sangat memuaskan.

3. Kemampuan pemecahan masalah matematis siswa kelompok rendah dengan setiap indikator :

a. Mengidentifikasi masalah berupa pemahaman apa yang diketahui tentang konsep isometric (S,M,R,G,H) memuaskan.

b. Mengidentifikasi masalah berupa pemahaman mahasiswa tentang apa yang ditanya tentang konsep isometric $\quad(\mathrm{S}, \mathrm{M}, \mathrm{R}, \mathrm{G}, \mathrm{H})$ cukup memuaskan.

c. Ketepatan urutan langkah yang digunakan mahasiswa cukup memuaskan.

d. Kebenaran tulisan dalam menjelaskan langkah terkategori kurang memuaskan.

e. Ketepatan/keterampilan dalam menggunakan jangka dan penggaris cukup memuaskan.

f. Ketepatan ukuran dalam melukis cukup memuaskan.

g. Kebenaran jawaban terkategori sangat kurang memuaskan.

Jadi secara keseluruhan kemampuan pemecahan masalah matematis siswa kelompok rendah terkategori cukup memuaskan.

\section{Saran}

Berdasarkan hasil penelitian maka disarankan beberapa hal sebagai berikut: (1) Perkuliahan Geometri hendaknya lebih ditingkatkan kepada aplikasi kontekstual agar perkuliahan lebih bermakna. (2) Memberikan keleluasaan bagi mahasiswa agar tercipta pola piker yang kritis dan kreatif sehingga memunculkan banyak ide. 


\section{DAFTAR RUJUKAN}

Ahmad Fauzan, Kemampuan Matematis: Pemecahan Masalah (evaluasi matematika.net) program pasca sarjana Universitas Negeri Padang, [3 Januari 2013]

Ali Hamzah, Evaluasi Pembelajaran Matematika. Jakarta: PT Raja Grafindo Persada. 2014.

Ali Mahmudi, 2008, Mengembangkan Soal Terbuka (Open-Ended Problem) dalam Pembelajaran Matematika,

http://www.google.com/url?sa=t\&r $\mathrm{ct}=\mathrm{j} \& \mathrm{q}=\&$ esrc $=\mathrm{s} \&$ source $=$ web\&cd $=1 \& \mathrm{cad}=\mathrm{rja} \& \mathrm{ved}=0 \mathrm{CCsQFjAA \& u}$ rl=http\%3A\%2F\%2Fstaff.uny.ac.i d\%2Fsites\%2Fdefault\%2Ffiles\%2 Fpenelitian\%2FAli\%2520Mahmud i\%2C\%2520S.Pd\%2C\%2520M.Pd $\% 2 \mathrm{C} \% 2520 \mathrm{Dr} . \% 2 \mathrm{FMakalah} \% 252$ 002\%2520PIPM\%25202008\%252

0_Mengembangkan\%2520Soal\%2 520Terbuka .pdf\&ei=i IKUsHeuh iAfJ6oHQBw\&usg=AFQjCNE4ol ONYs2m2WjPVoVNjRFkq4zQ\& bvm=bv.50723672,d.aGc, [akses 4 Maret 2013]

Depdiknas. Undang Undang Republik Indonesia No. 14 Tahun 2005 Tentang Guru dan Dosen, 2005. Available at:[http://www.depdiknas.go.id/inli nk.php?to=guru-dosen]. [akses September 2013]

Erman Suherman, Strategi Pembelajaran Matematika Kontemporer, (Bandung: Universitas Pendidikan Indonesia, 2003)

Hamzah B. Uno, Model Pembelajaran, (Jakarta: Bumi Aksara, 2008)

Hamzah Opu, Problem Posing dan Problem Solving dalam Pembelajaran Mateematika, (Bandung: Pustaka Ramadhan, 2003).

Max A. Sobel,ect. Teaching Mathematics: A Sourcebook of Aid, Activities, and Strategies. Terjemahan. Jakarta. Erlangga. 2002.

NCTM. 1989. Curriculum and Evaluation Standards for School Mathematics. Reston, VA: NCTM

Purwanto, Evaluasi Hasil Belajar, (Yogyakarta: Pustaka Pelajar, 2009)

Polya, George. 1956. How to Solve It Second Edition. New Jersey: Princetton University Press.

Uteri, Sumarmo. Berfikir dan Disposisi Matematik serta Pembelajarannya. (Kumpulan makalah). Bandung. FPMIPA UPI Bandung.2014 